\title{
PENGARUH PEMBERIAN JUS BIJI PEPAYA (CARICA PAPAYA LINN.) TERHADAP KADAR KOLESTEROL TOTAL TIKUS SPRAGUE DAWLY DISLIPIDEMIA
}

\author{
Neny Meirindasari, Hesti Murwani, Kusmiyati Tjahjono \\ Program Studi Ilmu Gizi Fakultas Kedokteran Universitas Diponegoro \\ Jl.Dr.Sutomo No.14, Semarang, Telp (024) 8453708, Email : gizifk@undip.ac.id
}

\begin{abstract}
Backgorund: Cardiovascular disease was the leading causes of death in the world. One of the cardiovascular risk factor was dislipidemia, defined as the abnormality of lipid profile in the blood. An appropriate management of cholesterol level could reduce risks of cardiovascular disease. Cholesterol level management could be treated with the consumption of functional food that have potential to reduce cholesterol level, for example papaya seed. Papaya seed contained flavonoid, saponin, tannin that had the potential to reduce blood cholesterol level. This study aimed to prove the effect of papaya seeds juice on total cholesterol level in dislipidemic rats.

Methods: A true experimental with pre-post test randomized control group design towards 28 Sprague Dawly dislipidemic rats which were randomized into 4 groups. There were negative control group that was given standard diet, positive control group that were given standard and high cholesterol diet, and two treatment groups that were given high cholesterol diet also papaya seeds juice at dosages $400 \mathrm{mg}$ and $800 \mathrm{mg}$ for 30 days. Total cholesterol level checked with spectrophotometry. Data were analysed by Paired t-test, Annova and LSD test with $95 \%$ CI.

Results: Alteration of the total cholesterol level in negative control, positive control, and treatment groups that were given papaya seeds juice at dosages $400 \mathrm{mg}$ and $800 \mathrm{mg}$ respectively $12.15 \%(p=0,178), 16,33 \%(p=0,192)$, $10,64 \%(p=0,221)$, and $-6,53 \%$ ( $p=0,536)$. Significancy between all of groups by Anova test was $p=0,241$.

Conclusion: The administration of papaya seeds juice for 30 days at dosages $400 \mathrm{mg} / \mathrm{rat} /$ day decreased total cholesterol level in dislipidemic rats.
\end{abstract}

Keywords: papaya seeds juice, flavonoid, saponin, tannin, total cholesterol

\begin{abstract}
ABSTRAK
Latar Belakang : Penyakit kardiovaskular merupakan penyebab utama kematian di dunia. Salah satu faktor risiko penyakit kardiovaskular adalah dislipidemia yaitu abnormalitas profil lipid dalam darah. Pengendalian kadar kolesterol yang tepat dapat mengurangi risiko penyakit kardiovaskular. Pengendalian kadar kolesterol dapat dilakukan dengan mengonsumsi pangan fungsional yang berpotensi menurunkan kadar kolesterol salah satunya adalah biji pepaya. Biji pepaya mengandung flavonoid, saponin, dan tanin yang berpotensi dalam menurunkan kadar kolesterol darah. Penelitian ini bertujuan untukmengetahui pengaruh jus biji pepaya terhadap kadar kolesterol total pada tikus dislipidemia.

Metode: Jenis penelitian ini adalah true experimental dengan pre-post test randomized control group design terhadap 28 ekor tikus Sprague Dawly dislipidemia yang kemudian dibagi secara acak dalam 4 kelompok yaitu kelompok kontrol negatif yang hanya diberikan pakan standar, kontrol positif yang diberikan pakan standar dan tinggi kolesterol, serta dua kelompok perlakuan yang diberikan pakan standar, tinggi kolesterol dan jus biji pepaya dengan dosis $400 \mathrm{mg}$ dan $800 \mathrm{mg}$ selama 30 hari. Kadar kolesterol total diperiksa dengan metode spektrofotometri. Data dianalisis dengan uji Paired t-test dan Anova serta uji Post-Hoc dengan LSD pada tingkat kepercayaan 95\%.

Hasil: Perubahan kadar kolesterol total kelompok kontrol negatif, kontrol positif dan perlakuan $400 \mathrm{mg}$ dan $800 \mathrm{mg}$ secara berturut-turut adalah 12,15\% ( $p=0,178), 16,33 \%(p=0,192),-10,64 \%(p=0,221)$, and $-6,53 \%(p=0,536)$. Perbedaan perubahan kadar kolesterol total antar kelompok dengan uji Anova menunjukkan signifikansi sebesar $0,241$.

Simpulan: Pemberian jus biji pepaya selama 30 hari pada dosis 400 mg/ekor/hari paling efektif menurunkan kadar kolesterol total pada tikus dislipidemia.
\end{abstract}

Kata kunci : Jus biji pepaya, flavonoid, saponin, tanin, kolesterol total

\section{PENDAHULUAN}

Penyakit kardiovaskular merupakan penyebab utama kematian dan penurunan produktivitas kerja di dunia. Faktor risiko utama penyakit jantung adalah dislipidemia karena kadar kolesterol total dan kolesterol LDL yang tinggi serta kadar kolesterol HDL yang rendah. Dislipidemia merupakan salah satu faktor penyebab disfungsi endotel yang dapat menyebabkan atherosklerosis. Pengendalian kadar kolesterol yang tepat dapat mengurangi risiko terjadinya penyakit jantung. ${ }^{1,2}$ Salah satu cara untuk mengendalikan kadar kolesterol adalah dengan modifikasi diet. Mengurangi asupan lemak jenuh dan kolesterol 
merupakan inti dari modifikasi diet. ${ }^{3}$ Modifikasi diet memberikan efek yang lebih aman sehingga sangat dianjurkan sebelum memutuskan terapi dengan menggunakan obat-obatan. Selain membatasi konsumsi kolesterol dan lemak jenuh, untuk menurunkan kadar kolesterol juga dianjurkan untuk mengonsumsi jenis-jenis bahan makanan yang memiliki efek hipolipidemik seperti biji pepaya.

Menurut penelitian terdahulu, pemberian jus biji pepaya pada tikus Sprague Dawley dapat menurunkan kadar kolesterol LDL secara signifikan. Pemberian jus biji pepaya dengan kadar $400 \mathrm{mg} / \mathrm{ekor} / \mathrm{hari}$ paling efektif dalam menurunkan kadar LDL. Dosis ini dapat menurunkan kadar LDL yang tidak berbeda dengan pemberian lovastatin. ${ }^{4}$ Penelitian yang dilakukan di Afrika menunjukkan bahwa ekstrak biji pepaya dapat menurunkan kadar trigliserida, kolesterol total, LDL, VLDL, serta meningkatkan kadar HDL secara signifikan dan progresif. Ekstrak biji pepaya cair yang diberikan sebanyak 100-400 $\mathrm{mg} /$ ekor/hari melalui peroral pada tikus Wistar jantan selama 30 hari. $^{5}$

Pepaya merupakan tanaman yang banyak dibudidayakan di Indonesia. Hampir semua bagian tanaman pepaya dapat dimanfaatkan, mulai dari buah, daun, batang, maupun akar. ${ }^{6}$ Akan tetapi, biji pepaya belum dimanfaatkan dengan baik oleh masyarakat karena hanya digunakan untuk keperluan pembibitan dan selebihnya dibuang, padahal biji pepaya memiliki kandungan gizi yang bermanfaat bagi kesehatan. Analisis fitokimia menunjukkan adanya alkaloid, flavonoid, saponin, tanin, antrakuinon, dan antosianosida.

Kandungan biji pepaya yang berpotensi menyebabkan efek hipokolesterolemik adalah flavonoid, saponin, dan tanin. Flavonoid merupakan antioksidan sehingga dapat mengurangi oksidasi kolesterol LDL yang diduga terlibat dalam perkembangan penyakit atherosklerosis. $^{7}$ Saponin dapat menurunkan kolesterol hati, menurunkan kadar trigliserida, serta meningkatkan eksresi fekal dari kolesterol. ${ }^{8}$ Tannin dalam biji pepaya dapat mengurangi absorbsi kolesterol di usus halus dan meningkatkan ekskresi asam empedu. ${ }^{9}$
Selama ini biji pepaya belum banyak diolah untuk dikonsumsi, peneliti mengolah biji pepaya menjadi jus agar zat gizi dalam biji pepaya tidak banyak yang hilang saat pengolahan dan agar sediaan dalam bentuk jus lebih mudah diaplikasikan di masyarakat.

Penelitian sebelumnya meneliti efek jus biji pepaya terhadap kolesterol LDL dengan dosis efektif $400 \mathrm{mg} / \mathrm{ekor} / \mathrm{hari}$. Dosis tersebut menurunkan kadar kolesterol LDL sebesar 55\% yang setara dengan penurunan akibat pemberian lovastatin. Hal inilah yang mendorong peneliti untuk melakukan penelitian dengan dosis yang lebih tinggi yaitu $800 \mathrm{mg} / \mathrm{ekor} / \mathrm{hari}$ yang bertujuan untuk melihat apakah dosis tersebut memiliki efek hipolipidemik yang lebih tinggi terhadap kadar kolesterol total tikus Sprague Dawley. Tikus jenis ini dipilih karena lebih sensitif terhadap diet tinggi lemak. Kolesterol total dipilih sebagai variabel terikat karena biasa digunakan sebagai skrining awal gangguan metabolisme lipid sebelum dilakukan pemeriksaan lebih lanjut. ${ }^{3}$

Berdasarkan uraian diatas, diteliti pengaruh pemberian jus biji pepaya terhadap kadar kolesterol total pada tikus Sprague Dawley dislipidemia.

\section{METODE PENELITIAN}

Jenis penelitian ini adalah eksperimental murni laboratorium dengan rancangan penelitian true experimental dengan pre-post test randomized control group design ${ }^{10}$. Penelitian ini dilaksanakan selama 2 bulan di Laboratorium Biologi Fakultas Matematika dan Ilmu Pengetahuan Alam Universitas Negeri Semarang (UNNES).

Subjek pada penelitian ini adalah 28 tikus jantan galur Sprague Dawley yang berumur 8 minggu (usia dewasa) dengan berat badan 150-180 gram yang diperoleh dari Laboratorium Farmasi Universitas Gajah Mada, Yogyakarta. Besar sampel penelitian ditentukan dengan rumus Federer $^{11}$ sehingga diperoleh sampel 7 ekor per kelompok perlakuan. Selama proses penelitian terdapat 4 ekor tikus yang mengalami drop out sehingga jumlah subjek pada akhir penelitian adalah 24 ekor.

Berikut adalah bagan alur penelitian : 
hari ke-1

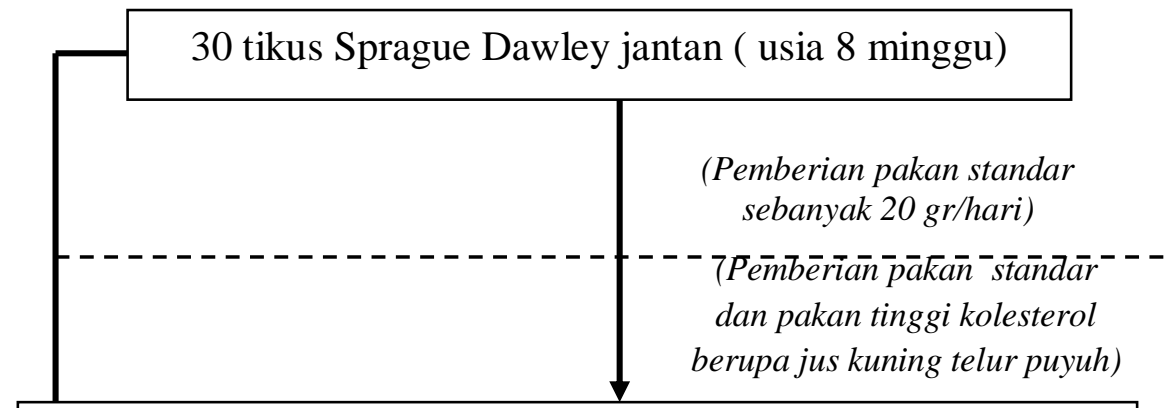

hari ke-28

Pengambilan darah, pemeriksaan kadar kolesterol total

hari ke-29

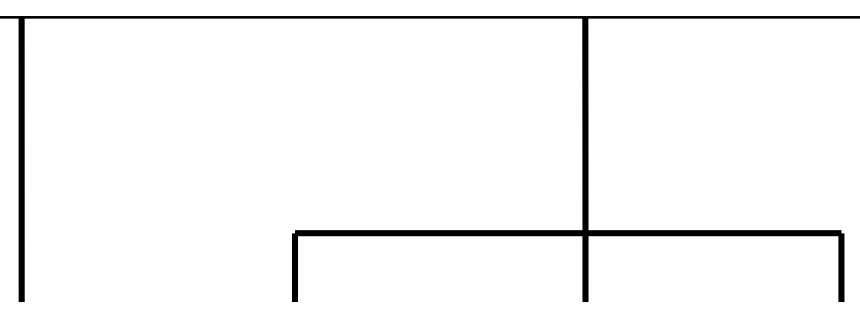

hari ke-49
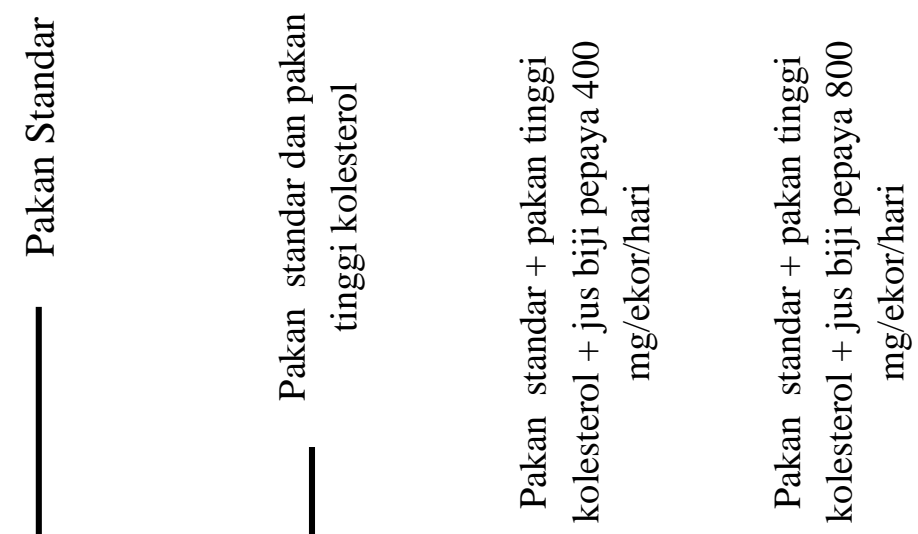

Pembuatan jus biji pepaya dilakukan dengan cara menghaluskan biji pepaya menggunakan blender, kemudian ditimbang sebanyak $400 \mathrm{mg}$. Setelah itu tambahkan air hingga $1 \mathrm{ml}$ lalu disaring. Air yang dibutuhkan untuk membuat jus biji pepaya $400 \mathrm{mg} / \mathrm{ml}$ adalah $580 \mathrm{mg}$, sehingga perbandingan biji pepaya dan air ialah $40: 58$. Untuk mendapatkan jus biji pepaya dengan kadar $800 \mathrm{mg}$ dapat mengambil $2 \mathrm{ml}$ dari kadar $400 \mathrm{mg}$ yang telah dibuat. Pemberian jus dan pakan tinggi kolesterol dilakukan dengan sonde.

Data yang diperoleh diolah dengan program komputer. Sebelumnya, data diuji normalitasnya dengan menggunakan uji Shapiro-Wilk. Perbedaan kadar kolesterol total sebelum dan sesudah perlakuan menggunakan uji $\mathrm{t}$ berpasangan. Perbedaan pengaruh dosis dari keempat kelompok perlakuan dianalisis menggunakan uji statistik

ANOVA dan uji lanjut LSD (Least Significant
Difference). ${ }^{12}$

\section{HASIL PENELITIAN}

Penelitian ini dilakukan untuk melihat pengaruh pemberian jus biji pepaya terhadap perubahan kadar kolesterol total tikus dislipidemia. Pada penelitian sebelumnya, jus biji pepaya telah terbukti menurunkan kadar kolesterol total tikus karena mengandung zat fitokimia berupa flavonoid, saponin, dan tanin.

\section{Perbedaan kandungan fitokimia biji pepaya dalam berbagai bentuk}

Kandungan zat fitokimia 100 gram biji pepaya dalam bentuk bahan utuh, jus tanpa disaring, dan jus yang disaring ditampilkan dalam tabel 1 berikut : 
Tabel 1. Kandungan zat fitokimia dalam 100 gram biji pepaya

\begin{tabular}{cccc}
\hline & $\begin{array}{c}\text { Jus biji pepaya } \\
\text { dengan disaring } \\
\text { (mg/100 g bahan) }\end{array}$ & $\begin{array}{c}\text { Jus biji pepaya } \\
\text { tanpa disaring } \\
\text { (mg/100 } \text { g bahan) }\end{array}$ & $\begin{array}{c}\text { Biji pepaya } \\
(\mathbf{m g} / \mathbf{1 0 0 g} \text { bahan })\end{array}$ \\
\hline Flavonoid & 263,6 & 294,4 & 947,7 \\
Saponin & 28,3 & 31,4 & 88,39 \\
Tanin & 57,5 & 61,6 & 189,35 \\
\hline
\end{tabular}

Analisis fitokimia pada tabel 1 diperoleh dari Laboratorium Kimia Universitas Muhammadiyah Malang. Uji fitokimia dilakukan untuk membandingkan kandungan fitokimia dalam biji pepaya utuh, jus tanpa disaring, dan jus yang disaring. Berdasarkan tabel diatas dapat disimpulkan bahwa biji pepaya utuh memiliki kandungan flavonoid, saponin, dan tanin yang paling tinggi dibandingkan bentuk lainnya.

\section{Berat badan subjek}

Tabel 2 menampilkan perbedaan berat badan awal dan akhir penelitian untuk melihat keterkaitan antara perubahan berat badan dengan asupan pakan subyek.

Tabel 2. Rata-rata berat badan awal dan akhir penelitian

\begin{tabular}{|c|c|c|c|c|}
\hline $\begin{array}{l}\text { Berat } \\
\text { Badan }\end{array}$ & $\mathrm{n}$ & $\begin{array}{c}\text { Sebelum } \\
\text { (gram) }\end{array}$ & $\begin{array}{c}\text { Sesudah } \\
\text { (gram) }\end{array}$ & $\mathrm{p}$ \\
\hline K- & 6 & $\begin{array}{c}207,96 \pm 22 \\
98\end{array}$ & $\begin{array}{c}262,82 \pm 30 \\
73\end{array}$ & $0,000 *$ \\
\hline $\mathrm{K}+$ & 6 & $\begin{array}{c}203,69 \pm 11 \\
83\end{array}$ & $\begin{array}{c}263,81 \pm 22 \\
51\end{array}$ & $0,003^{*}$ \\
\hline $\mathrm{Pa}$ & 6 & $\begin{array}{c}219,83 \pm 23 \\
53\end{array}$ & $\begin{array}{c}283,02 \pm 17 \\
45\end{array}$ & $0,000 *$ \\
\hline $\mathrm{Pb}$ & 6 & $\begin{array}{c}211,94 \pm 9,6 \\
6\end{array}$ & $\begin{array}{c}277,94 \pm 19 . \\
84\end{array}$ & $0,000 *$ \\
\hline
\end{tabular}

Paired t-test *berbeda bermakna

Keterangan : K- : kelompok kontrol negatif

$\mathrm{K}+$ :kelompok kontrol positif

P1 : kelompok perlakuan jus biji papaya $400 \mathrm{mg}$

P2 : kelompok perlakuan perlakuan jus biji papaya $800 \mathrm{mg}$

Tabel 2 menunjukkan bahwa terdapat perbedaan berat badan secara signifikan antara

awal dan akhir penelitian pada seluruh kelompok.

Tabel 3. Perubahan berat badan subjek antar kelompok perlakuan

\begin{tabular}{ccccc}
\hline Kelompok & $\mathbf{n}$ & $\begin{array}{c}\boldsymbol{\Delta} \mathbf{B B} \\
(\mathbf{g r a m})\end{array}$ & $\mathbf{\%} \boldsymbol{\Delta} \mathbf{B B}$ & $\boldsymbol{P}$ \\
\hline $\mathrm{K}-$ & 6 & $54,86 \pm 14,34$ & $26,38 \%$ & \\
$\mathrm{~K}+$ & 6 & $60,12 \pm 27,22$ & $29,52 \%$ & 0,717 \\
$\mathrm{~Pa}$ & 6 & $63,19 \pm 8,49$ & $28,75 \%$ & \\
$\mathrm{~Pb}$ & 6 & $66,01 \pm 13,52$ & $31,15 \%$ & \\
\hline
\end{tabular}

Uji ANOVA *berbeda bermakna

Keterangan : K- : kelompok kontrol negatif

$\mathrm{K}+$ :kelompok kontrol positif

P1 : kelompok perlakuan jus biji papaya $400 \mathrm{mg}$

P2 : kelompok perlakuan perlakuan jus biji papaya $800 \mathrm{mg}$

Berdasarkan tabel 3 diatas diketahui bahwa rata-rata perubahan berat badan yang terendah adalah sebesar $54,86 \pm 14,3$ gram yaitu pada kelompok kontrol negatif dan perubahan berat badan tertinggi yaitu sebesar 66,00 $\pm 13,53$ gram pada kelompok perlakuan kedua. Hasil uji ANOVA dilakukan untuk melihat perbedaan perubahan berat badan antar kelompok, diperoleh 
nilai signifikansi sebesar $0,717(\mathrm{p}>0,05)$ sehingga dapat disimpulkan tidak terdapat perbedaan perubahan berat badan antar kelompok.

\section{Asupan selama intervensi}

Asupan perhari selama intervensi ditunjukkan pada gambar 1

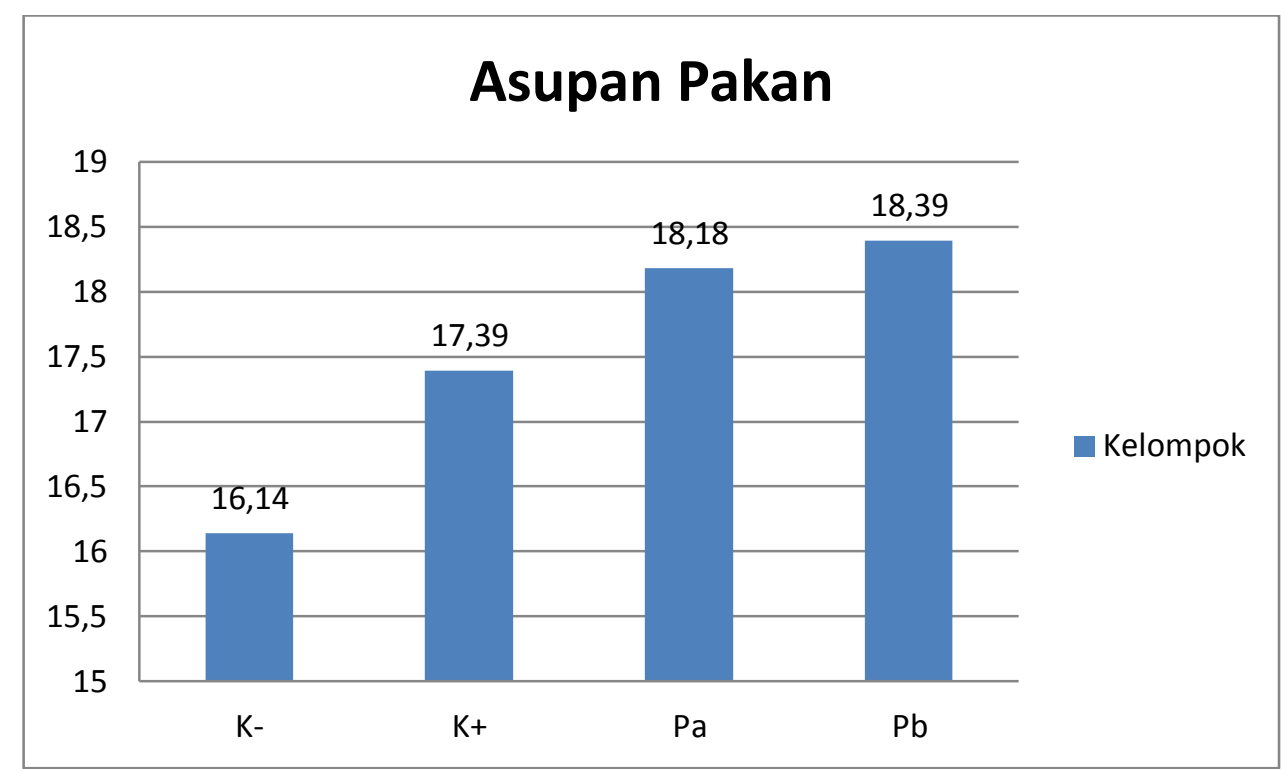

Gambar 1. Diagram asupan pakan selama intervensi pada masing-masing kelompok

Gambar 1 menunjukkan bahwa rerata asupan pakan perhari yang paling tinggi adalah pada kelompok perlakuan kedua yaitu sebesar 18,39 gram sedangkan yang paling rendah adalah pada kelompok kontrol negatif yaitu sebesar 16,14 gram. Dapat disimpulkan bahwa faktor yang mendorong peningkatan berat badan subjek pada kelompok perlakuan kedua adalah banyaknya pakan yang diasup.

\section{Analisis Kadar Kolesterol Total Sebelum dan Sesudah Perlakuan}

Sebelum intervensi, 28 ekor tikus mengalami masa aklimatisasi atau masa adaptasi dan keadaan dislipidemia. Setelah dilakukan pengambilan darah awal, dilakukan intervensi berupa jus biji pepaya dengan dosis yang berbeda selama 30 hari.

Tabel 4. Hasil Analisis Kadar Kolesterol Total

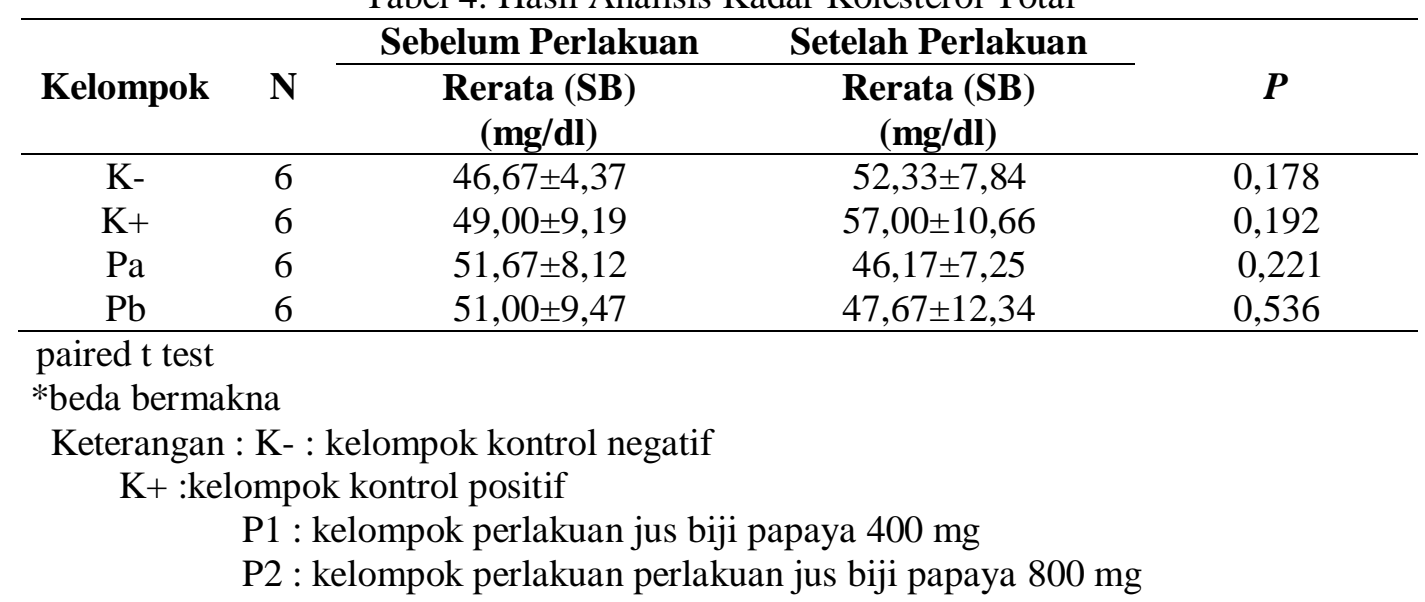

Tabel 4 menunjukkan bahwa tidak terdapat perbedaan kadar kolesterol total sebelum dan sesudah intervensi $(\mathrm{p}>0,05)$ pada kelompok perlakuan. Seluruh kelompok yang diberi perlakuan jus biji pepaya terlihat mengalami penurunan kadar kolesterol total, namun secara statistik tidak bermakna. 
Analisis Kadar Kolesterol Total Awal dan Akhir Intervensi

Gambaran perbedaan kadar kolesterol total awal sebelum dan sesudah dilakukan intervensi antar kelompok perlakuan yang diuji dengan ANOVA ditampilkan pada tabel 5 berikut :

Tabel 5. Kadar kolesterol total antar kelompok perlakuan

\begin{tabular}{|c|c|c|c|c|c|}
\hline \multirow{2}{*}{ Variabel } & \multicolumn{4}{|c|}{ Rerata (mean \pm SD) } & \multirow[b]{2}{*}{$\mathrm{p}$} \\
\hline & $\mathrm{K}-(\mathrm{n}=6)$ & $K+(n=6)$ & $\mathrm{Pa}(\mathrm{n}=6)$ & $\mathrm{Pb}(\mathrm{n}=6)$ & \\
\hline $\begin{array}{l}\text { Kolesterol } \\
\text { total awal } \\
(\mathrm{mg} / \mathrm{dl})\end{array}$ & $46,67 \pm 4,37$ & $49,00 \pm 9,19$ & $\begin{array}{c}51,67 \pm 8,1 \\
2\end{array}$ & $51,00 \pm 9,47$ & $\begin{array}{c}0,70 \\
7\end{array}$ \\
\hline $\begin{array}{l}\text { Kolesterol } \\
\text { total akhir } \\
(\mathrm{mg} / \mathrm{dl})\end{array}$ & $52,33 \pm 7,84$ & $\begin{array}{c}57,00 \pm 10,6 \\
6\end{array}$ & $\begin{array}{c}46,17 \pm 7,2 \\
5\end{array}$ & $\begin{array}{c}47,67 \pm 12,3 \\
4\end{array}$ & $\begin{array}{c}0,24 \\
1\end{array}$ \\
\hline
\end{tabular}

Uji ANOVA *berbeda bermakna

Keterangan : K- : kelompok kontrol negatif

$\mathrm{K}+$ :kelompok kontrol positif

P1 : kelompok perlakuan jus biji papaya $400 \mathrm{mg}$

P2 : kelompok perlakuan perlakuan jus biji papaya $800 \mathrm{mg}$

Berdasarkan uji ANOVA kadar kolesterol total diatas diperoleh nilai signifikansi sebesar 0,707 $(p>0,05)$ yang menunjukkan tidak terdapat perbedaan antar kelompok perlakuan sebelum intervensi. Sedangkan untuk uji ANOVA sesudah intervensi, diperoleh nilai signifikansi sebesar
0,241 ( $\mathrm{p}>0,05$ ) yang menunjukkan bahwa tidak terdapat perbedaan bermakna antar kelompok perlakuan sesudah dilakukannya intervensi.

\section{Analisis Perbedaan Perubahan Kadar Kolesterol Total}

Tabel 6. Hasil Analisis Perbedaan Perubahan Kadar Kolesterol Total

\begin{tabular}{|c|c|c|c|c|}
\hline \multirow[b]{2}{*}{ Kelompok } & \multirow[b]{2}{*}{$\mathbf{N}$} & $\Delta$ Kolesterol Total & $\% \Delta$ Kolesterol total & \multirow[b]{2}{*}{$\boldsymbol{P}$} \\
\hline & & $\begin{array}{c}\text { Rerata (SB) } \\
(\mathbf{m g} / \mathbf{d l})\end{array}$ & & \\
\hline K- & 6 & $5.67 \pm 8.87$ & $12.15 \%$ & \multirow{4}{*}{$0,12^{\prime}$} \\
\hline $\mathrm{K}+$ & 6 & $8.00 \pm 12,99$ & $16,33 \%$ & \\
\hline $\mathrm{Pa}$ & 6 & $-5.50 \pm 9.65$ & $-10,64 \%$ & \\
\hline $\mathrm{Pb}$ & 6 & $-3.33 \pm 12,31$ & $-6,53 \%$ & \\
\hline
\end{tabular}

Keterangan : K- : kelompok kontrol negatif

$\mathrm{K}+$ :kelompok kontrol positif

P1 : kelompok perlakuan perlakuan jus biji papaya $400 \mathrm{mg}$

P2 : kelompok perlakuan perlakuan jus biji papaya $800 \mathrm{mg}$

Tabel 6 menunjukkan perbedaan perubahan kadar kolesterol total sebelum dan sesudah perlakuan. Hasil uji beda rerata kolesterol total antar kelompok menunjukkan bahwa kelompok perlakuan pertama dan kedua mengalami penurunan kadar kolesterol total sesudah dilakukan intervensi, sedangkan pada kelompok kontrol positif dan negatif menunjukkan peningkatan kadar kolesterol total. Dari hasil uji ANOVA diperoleh nilai signifikansi sebesar 0,127 ( $>0,05$ ) sehingga dapat disimpulkan bahwa tidak terdapat perbedaan perubahan kadar kolesterol total antar kelompok perlakuan. Secara deskriptif pemberian jus biji pepaya pada dosis $400 \mathrm{mg}$ lebih efektif menurunkan kadar kolesterol total dibandingkan dosis $800 \mathrm{mg}$ yaitu sebesar $10,64 \%$. Jus biji pepaya dengan dosis $800 \mathrm{mg}$ tetap memberikan efek penurunan yaitu sebesar $6,53 \%$ walaupun secara statistik tidak bermakna.

\section{PEMBAHASAN \\ Berat Badan}

Hasil pengukuran berat badan yang dilakukan setiap hari menunjukkan bahwa terdapat perbedaan berat badan secara signifikan antara awal dan akhir penelitian pada semua kelompok 
perlakuan. Perubahan berat badan yang paling tinggi terdapat pada kelompok perlakuan kedua yaitu sebesar $31,15 \%$ dan yang paling rendah adalah kelompok kontrol negatif yaitu sebesar 26,38\%. Hal ini terjadi karena kelompok kontrol negatif hanya diberikan pakan standar sebanyak 20 gram/hari, sedangkan pada kelompok kontrol positif, kelompok perlakuan pertama, dan kelompok perlakuan kedua diberikan pakan standar sebanyak 20 gram/hari ditambah dengan jus kuning telur puyuh sebanyak $2 \mathrm{ml}$ yang diberikan lewat sonde hingga akhir penelitian. Pakan tinggi kolesterol yang diberikan berupa kuning telur puyuh karena mengandung kadar kolesterol yang lebih tinggi dibanding telur lain. ${ }^{13}$ Peningkatan berat badan sesuai dengan hasil penelitian sebelumnya bahwa pemberian telur puyuh sebanyak $2 \mathrm{ml}$ selama 28 hari dapat meningkatkan berat badan sebesar $80,7 \% .^{14}$

Peningkatan berat badan yang paling tinggi terdapat pada kelompok perlakuan kedua karena memiliki asupan pakan yang paling tinggi dibandingkan dengan kelompok lainnya yaitu sebesar 18,39 gram/hari. Semakin banyak pakan yang diasup oleh tikus, maka semakin bertambah pula berat badannya.

\section{Kandungan gizi jus biji pepaya}

Uji fitokimia dilakukan untuk mengetahui perbedaan kandungan fitokimia dalam bentuk biji pepaya utuh, jus tanpa disaring, dan jus yang tidak disaring. Uji ini dilakukan di laboraturium kimia Universitas Muhammadiyah Malang. Berdasarkan hasil uji fitokimia yang tersaji dalam tabel 1 terlihat bahwa terdapat perbedaan kandungan fitokimia antar bahan. Dalam 100 gram biji pepaya utuh memiliki kandungan flavonoid, saponin dan tanin yang paling tinggi sedangkan jus biji pepaya saring memiliki kandungan flavonoid, saponin dan tanin yang paling rendah. Biji pepaya utuh memiliki kandungan fitokimia yang lebih tinggi dibanding dalam bentuk jus karena dalam proses pembuatan jus terdapat penambahan air sehingga konsentrasi biji pepaya dalam jus berkurang yang menyebabkan kandungan flavonoid dalam jus menurun. Jus biji pepaya saring memiliki kandungan fitokimia yang paling rendah karena selain ditambahkan air, juga dilakukan penyaringan dalam proses pembuatannya sehingga banyak biji pepaya yang terbuang saat proses penyaringan yang menyebabkan kandungan flavonoid dalam jus menurun. Akan tetapi, perlakuan terhadap tikus percobaan dalam penelitian ini diberikan jus biji pepaya saring karena terdapat kesulitan dalam proses penyondean jika perlakuan diberikan dalam bentuk biji pepaya utuh maupun dalam bentuk jus biji pepaya tanpa disaring. Hasil uji fitokimia ini sesuai dengan penelitian sebelumnya yang dilakukan di Afrika bahwa biji pepaya mengandung flavonoid, tanin, dan saponin. ${ }^{5}$

\section{Pemberian Pakan Tinggi Kolesterol}

Pada penelitian ini untuk menginduksi dislipidemia pada tikus digunakan pakan tinggi kolesterol berupa jus kuning telur puyuh sebanyak $2 \mathrm{ml}$ yang mengandung kadar kolesterol sebanyak $42,78 \mathrm{mg}$ serta diberikan lewat sonde. Kuning telur puyuh dipilih karena memiliki kandungan kolesterol yang paling tinggi dibandingkan dengan kuning telur lain yaitu sebesar 2139,17 mg/100 gram sehingga diharapkan mampu meningkatkan kadar kolesterol total. ${ }^{13}$

Keadaan dislipidemia diketahui dengan cara membandingkan kadar kolesterol total tikus yang mendapat pakan tinggi kolesterol (kontrol positif, perlakuan pertama dan perlakuan kedua) dengan kelompok kontrol negatif yang mendapat pakan standar. Fungsi kelompok kontrol negatif adalah sebagai gambaran kadar kolesterol tikus normal.

Hasil analisis beda rerata menunjukkan bahwa setelah pemberian pakan tinggi kolesterol tidak terdapat perbedaan kadar kolesterol total antar kelompok. Namun secara deskriptif, kelompok perlakuan kedua memiliki kadar kolesterol total paling tinggi dibandingkan dengan kelompok lain yaitu sebesar, 51,67 mg/dl diikuti dengan kelompok perlakuan pertama yaitu sebsar $51 \mathrm{mg} / \mathrm{dl}$. Hal tersebut dikarenakan kelompok perlakuan kedua memiliki asupan makan dan perubahan berat badan yang paling tinggi dibandingkan dengan dengan kelompok lain. Berat badan yang berlebih dapat menyebabkan peningkatan kolesterol dalam tubuh karena tingginya penyimpanan trigiserida dibawah kulit yang merupakan sumber utama pembentukan VLDL dan LDL di liver yang bersirkulasi dalam darah. ${ }^{15}$

\section{Pengaruh Jus Biji Pepaya terhadap Kadar Kolesterol Total}

Jus biji pepaya diharapkan mampu menurunkan kadar kolesterol total. Pada penelitian ini, kadar kolesterol total setelah intervensi antar kelompok tidak menunjukkan adanya perbedaan yang bermakna secara statistik. Namun, secara deskriptif kadar kolesterol total setelah intervensi pada kelompok perlakuan jus biji pepaya $400 \mathrm{mg}$ dan jus biji pepaya $800 \mathrm{mg}$ mengalami penurunan masing-masing sebesar $10,64 \%$ dan $6,53 \%$. 
Penurunan kadar kolesterol total disebabkan kandungan fitokimia berupa flavonoid, tanin, dan saponin yang ada dalam jus biji pepaya. Flavonoid diketahui dapat menurunkan kadar kolesterol total karena merupakan kofaktor dari enzim kolesterol esterase. Selain itu flavonoid dapat meningkatkan ekskresi getah empedu melalui pengaktifan enzim sitokrom P-450. Enzim sitokrom P-450 mengikat beberapa komponen dalam getah empedu sehingga mengurangi kadar kolesterol di dalam tubuh. ${ }^{19}$ Saponin dalam jus biji pepaya membentuk kompleks tidak larut dengan kolesterol sehingga mencegah absorbsi kolesterol di usus halus. Selain itu saponin mengurangi absorbsi getah empedu dengan membentuk kompleks misel yang tidak dapat diabsorbsi karena berat molekulnya terlalu besar. ${ }^{8}$ Sedangkan tanin dalam biji pepaya dapat mengurangi absorbsi kolesterol di usus halus dan meningkatkan ekskresi asam empedu dengan mekanisme yang sama seperti saponin serta dapat meningkatkan reverse cholesterol transport. ${ }^{9}$ Belum dapat diketahui apakah flavonoid, saponin, maupun tanin yang paling berpengaruh dalam menurunkan kolesterol total.

Hasil penelitian ini sesuai dengan penelitian sebelumnya bahwa jus biji pepaya dapat menurukan kadar kolesterol LDL secara signifikan. ${ }^{4}$ Penurunan kadar kolesterol LDL akibat pemberian jus biji pepaya pada dosis 100 $\mathrm{mg}, 200 \mathrm{mg}$, dan $400 \mathrm{mg}$ adalah sebesar 23\%, $40 \%$, dan $55 \%$. Rendahnya penurunan kadar kolesterol total jika dibandingkan dengan penelitian sebelumnya diakibatkan subyek penelitian diberikan pakan tinggi kolesterol hingga akhir intervensi, sedangkan pada penelitian sebelumnya pakan tinggi kolesterol diberikan hingga terjadi kondisi dislipidemia dan tidak diteruskan hingga akhir penelitian.

\section{KETERBATASAN PENELITIAN}

Keterbatasan dalam penelitian ini adalah tidak dilakukan uji serat dan kandungan flavonoid secara spesifik.

\section{SIMPULAN}

Pemberian jus biji pepaya selama 30 hari pada dosis $400 \mathrm{mg} / \mathrm{ekor} /$ hari dan $800 \mathrm{mg} / \mathrm{ekor} / \mathrm{hari}$ tidak dapat menurunkan kadar kolesterol total pada tikus dislipidemia secara signifikan.

\section{SARAN}

Diperlukan penelitian lebih lanjut menggunakan bentuk lain dari biji pepaya sebagai contoh bentuk bubuk serta penelitian lebih lanjut mengenai efek pemberian jus biji pepaya dengan menggunakan subjek manusia.

\section{UCAPAN TERIMA KASIH}

Penulis mengucapkan terima kasih kepada semua pihak yang telah membantu dalam penyusunan Karya Tulis Ilmiah ini, terima kasih penulis sampaikan kepada para reviewer yaitu dr. Yekti Wirawanni dan dr. Kusmiyati DK, M.Kes atas kritik dan saran yang diberikan.

\section{DAFTAR PUSTAKA}

1. Ballanntyne CM, O'Keefe, Gotto AM. Dyslipidemia and Atherosclerosis Essentials Fourth Edition. Massachussetts: Jones and Bartlett Publishers; 2009. 5-6.

2. Mahan LK, Stump ES. Krause's Food, Nutrition, and Diet Theraphy $12^{\text {th }}$ edition. Pensylvania : Saunders; 2007.

3. Third Report of the National Cholesterol Education Program (NCEP) Expert Panel on Detection, Evaluation, and Treatment of High Blood Cholesterol in Adults (Adult Treatment Panel III) Final Report.

4. Nuraini M. Pengaruh Pemberian Jus Biji Pepaya (Carica papaya Linn) terhadap Penurunan Kadar Low Density Lipoproteins (LDL) Plasma Tikus Sprague Dawly. Skripsi. Yogyakarta: Program Sarjana Kedokteran dan Ilmu Kesehatan, Universitas Muhammadiyah Yogyakarta.

5. Adeneye AA, Olagunju JA. Preliminary hypoglycemic and hypolipidemic activities of the aqueous seed extract of Carica papaya Linn. in Wistar rats. Biology and Medicine, Vol. 1 (1): 1-10, 2009.

6. Warisno. Budidaya Pepaya. Yogyakarta: Kanisius; 2003.

7. Knektm P, Kumpulainen J, Järvinen R, Rissanen H, Heliövaara M, Reunanen A et al. Flavonoid intake and cardiovascular disease mortality: a prospective study in postmenopausal women. Am J Clin Nutr 2007;85:895-909.

8. Matsui Y, Kobayashi K, Masuda H, Kigoshi H, Akao M, Sakurai H. Quantitative Analysis of Saponins in a Tea-Leaf Extract and Their Antihypercholesterolemic Activity. Biosci. Biotechnol. Biochem., 73 (7), 1513-1519, 2009.

9. Tebib K, Besancon P, Rouanet JM. Dietary Grape Seed Tannins affect Lipoproteins, Lipoprotein Lipases and Tissue Lipids in Rats Fed Hypercholesterolemic Diets. J Nutr 1994; 124: 2451-2458.

10. Supranto J. Teknik Sampling untuk Survei dan Eksperimen. Jakarta : Penerbit PT Rineka Cipta; 2000. 
11. Hidayat, A Aziz Alimul. Metode Penelitian Kesehatan. Surabaya : Health Books Publishing ; 2010.

12. Dahlan, MS. Statistik untuk Kedokteran dan Kesehatan. Jakarta : Salemba Medika; 2008.

13. Dwiloka B. Efek Kolesterolemik berbagai Telur. Media Gizi \& Keluarga. 2003 ; 27(2) : 58-65

14. Rully M, Probosari E. Pengaruh pemberian Buah Pepaya (Carica Papaya Linn.) terhadap Kadar Trigliserida pada Tikus Sprague Dawley dengan
Hiperkolesterolemia (skripsi). Semarang: Universitas Diponegoro.; 2012.

15. Soeharto, Iman. Penyakit Jantung Coroner dan Serangan Jantung Edisi Kedua. Jakarta : PT. Gramedia Pustaka Utama. 2004.

16. Oliveira TT, Ricardo KF, Almeida MR, Costa MR, Nagem TJ. Hypolipidemic Effect of Flavonoids and Cholestyramine in Rats. Lat. Am. J. Pharm. 26 (3): 407-10 (2007). 